of early thrombolysis, with tissue plasminogen activator (the ASSET study) is eagerly awaited, but until this becomes available tissue plasminogen activator should probably be used only in those who have received streptokinase in the preceding six months. On the other hand, the AIMS study (APSAC infarction mortality study) with anisolyated plasminogen streptokinase activator complex (APSAC), now called anistreplase, did show a reduction in mortality of almost half at one month and one year after infarction, which is greater than that for streptokinase in the second international study on infarct survival and the Italian study. The confidence intervals of these studies overlap, however, and until direct comparative studies of the two agents are undertaken it will be impossible to be sure whether anistreplase is superior. Furthermore, we will have to know whether adding aspirin to anistreplase is as effective as adding it to streptokinase. Anistreplase does have the important advantage that it needs simply a five minute intravenous injection rather than a one hour infusion.

Thrombolytic treatment should now be routine in acute myocardial infarction and be given as early as possible. Major changes must therefore take place. At present many patients do not reach hospital until four to five hours after the onset of the event and may then spend one to two hours in the casualty department without specific treatment. This is unacceptable, and the organisation of care must be greatly improved.

One delay is that imposed by the general practitioner. When there are rapid response teams general practitioners may attend the patient very quickly and then be able to make the diagnosis, provide initial treatment, and expedite admission to hospital. Other general practitioners may find it impracticable to attend patients promptly, in which case the ambulance service should take on the responsibility for immediate care and the rapid transit of the patient to hospital. General practitioners must decide whether they are able to provide prompt care or whether they wish to devolve this to the ambulance service.
The accident and emergency department may be a dangerous place for the patient with myocardial infarction unless there is a rapid response from the admitting medical team. Speed was already important when the contribution of hospital care lay in correcting life threatening arrhythmias, but it has been given added importance by thrombolytic treatment. Indeed, direct admission to cardiac care units may have great advantages.

Doctors have a poor record of translating the findings of clinical trials into practice. This is not surprising when the benefits are marginal, but the benefits of thrombolytic treatment and aspirin are of such a magnitude that they may save thousands of lives in Britain within the next year. The task of implementing these important advances is not for cardiologists or hospital doctors alone. General practitioners and administrators of the National Health Service must also respond to this challenge.

Consultant Medical Director,

DESMOND G JULIAN

British Heart Foundation,

London W1H 4DH

Consultant Physician,

General Hospital,

Birmingham $\mathrm{B} 46 \mathrm{NH}$

Consultant Cardiologist,

Royal Sussex County Hospital,

Brighton BN2 5BE

DOUGLAS A CHAMBERLAIN

1 ISIS-2 (Second International Study of Infarct Survival) Collaborative Group. Randomised trial of intravenous streptokinase, oral aspirin, both, or neither among 17187 cases of suspected acute myocardial infarction: ISIS-2. Lancet 1988;ii:349-60.

2 Marder VJ, Sherry S. Thrombolytic therapy: current status. N Engl f Med 1988;318:1512-20.

3 Gruppo Italiano per to Studio della Streptochinasi nell'Infarto Miocardico (GISSI). Long-term effects of intravenous thrombolysis in acute myocardial infarction: final report of the GISSI study. Lancet 1987;ii:871-4.

4 Gruppo Italiano per lo Studio della Streptochinasi nell'Infarto Miocardico (GISSI). Effectiveness of intravenous thrombolytic treatment in acute myocardial infarction. Lancet 1986;i:397-402.

AIMS Trial Study Group. Effect of intravenous APSAC on mortality after acute myocardial infarction: preliminary report of a placebo-controlled clinical trial. Lancet 1988;i:545-9.

\title{
I do not love thee Mr Fell....
}

\section{Techniques for dealing with "heartsink" patients}

The best interests of both patients and doctors are served by maintaining the image of excellent relationships between the two groups. For that reason, perhaps, the subject of patients who are disliked is something of a mystery. It is not on medical school curriculums, and there are few published reports.

There are, however, clues. For instance, Cartwright and Anderson found that $24 \%$ of general practitioners described more than half of their work as trivia.' Those who consult doctors much more frequently than the average have been defined in various ways and studied by various methods..$^{2-8} \mathrm{~A}$ seventh of patients account for almost half of all doctorpatient contacts, ${ }^{2}$ with a twentieth accounting for a fifth of contacts. ${ }^{6}$ A study of families in a deprived part of Aberdeen failed to identify a single explanation for overconsulting but noted that the reasons for consulting might depend less on the symptoms than on the immediate circumstances in the family. ${ }^{5}$ Controlled studies found frequent attenders to have more symptoms overall and fewer symptom free days than controls. ${ }^{8}$ They were also judged to have poorer coping strategies and less rich social lives ${ }^{8}$ and to have a higher chance of being single or suffering from family dysfunction, ${ }^{8}$ echoing findings on the origins of depression. ${ }^{9}$ One author expressed surprise at finding that as many as two fifths of frequent attenders had diagnoses of organic disease. ${ }^{2}$ Others have seen the problem as being one of emotional ${ }^{6}$ or neurotic origin. ${ }^{3}$

At one extreme are the patients, not always frequent attenders, towards whom doctors feel active antipathy, and two studies are published this week on the subject ( $\mathrm{p} 528$ and p 530). Whether described as difficult (p 530), "10 "heartsink" (p 528), problem patients, ${ }^{11}$ dysphoric, ${ }^{12}$ or hateful, ${ }^{13}$ they share the capacity to make doctors feel inadequate or useless. They may do this, for instance, by making excessive demands, rejecting attempts to help, or denying important aspects of their history or illness. Some patients may feel themselves to be guilty and are manipulating their doctors into rejecting them in order to punish themselves. ${ }^{14}{ }^{15}$ Encounters with these patients may induce despair, frustration, and a sense of humiliating failure in doctors, preventing the patients from getting the best medical advice. ${ }^{16}$ As a group they contain a higher proportion of women and are likely to suffer from chronic disease (p 528). ${ }^{10}$ Hospital patients unpopular with nurses, on the other hand, are more likely to have a psychiatric diagnosis. ${ }^{17}$ 
Three other conclusions emerge from these studies. Firstly, contrary to gut feelings, the group of patients described either as frequent attenders or "heartsink" does not remain static but changes over several years ( $p$ 528). ${ }^{418}$ The needs that are being satisfied by their behaviour are neither constant nor indefinite.

Secondly, despite the honesty of these writers they all focus on the patients' characteristics rather than on the contribution of their own personality to the problem. For instance, a study of patients with systemic lupus erythematosus found that four doctors most disliked patients with psychiatric symptoms. The authors concluded that dislike could be used as a diagnostic tool to predict psychiatric illness but did not consider whether this showed a prejudice among the doctors. ${ }^{14}$ This is an example of attribution bias, in which the observer takes credit for success and denies responsibility for failure. ${ }^{20}$ Exceptionally, Illingworth has admitted that irritation often arises from the doctor's intolerance, impatience, fatigue, hunger, or pressure of work. ${ }^{21}$

Thirdly, this painful topic has been avoided by most British hospital doctors. This may be because these feelings usually arise in long term relationships, which most hospital doctors are not required to form.

Balint's pioneering work with general practitioners showed the value of small groups for exploring sensitive areas of practice. ${ }^{22}$ Such groups provide a constructive setting for the first step in dealing with negative feelings: admitting their existence to ourselves and our peers and drawing up an agreed policy for individual patients. ${ }^{15}{ }^{16}$ Ideally, the policy could be negotiated with the patients themselves, but the fact that they have acquired the label "heartsink" may mean that it has already been difficult for the practice to agree goals with them. At best, doctors' negative emotions may be discussed and used as part of treatment to explore the reasons patients have for wanting to punish doctors and be punished by them. Many doctors and patients will find this technique too difficult or intrusive; as O'Dowd's study hints some patients will choose to find another doctor with whom they can maintain a more distant relationship ( $\mathrm{p} 528$ ). Doctors should assess how much of the problem is attributable to their own attitudes or working practices. Getting outside their own emotions will also help them to see the problems from patients' points of view; some of the irritation will be reduced by empathetic understanding shared with colleagues.

Such a programme will not make all patients more likeable. Some will continue to evoke negative feelings whatever is tried. For them doctors should state clearly what they can and cannot provide so that they can answer patients' medical needs without spending too much of their own time in unrewarding or humiliating encounters. ${ }^{12}$

Consultant Senior Lecturer in General Practice,

DAVID JEWELL

University of Bristol,

Department of Epidemiology and Community Medicine,

Canynge Hall,

Bristol BS8 2LA

1 Cartwright A, Anderson R. General practice revisited. London: Tavistock, 198.1.

2 Wamoscher $Z$. The returning patient. $\mathcal{J} R$ Coll Gen Pract 1966;11:166-73.

3 Semmence A. Chronic high users in a general practice. $f$ R Coll Gen Pract 1969;17:304-10.

4 Courtenay MJF, Curwen MP, Dawe D, Robinson J, Stern MJ. Frequent attendance in a family practice. $\mathcal{F} R$ Coll Gen Pract 1974;24:251-61.

practice. $R$ Coll Gen Praci Dawe D, Robi:251.61. 1982:32:657-62.

6 Browne GB, Humphrey B, Pallister R, Browne JA, Shetzer L. Prevalence and characteristics of frequent attenders in a prepaid Canadian family practice. F Fam Pract 1982;14:63-71.

Westhead JN. Frequent attenders in general practice: medical, psychological and social haracteristics. I R Coll Gen Pract 1985;35:337-40.

8 Robinson JO, Granfield AJ. The frequent consulter in primary medical care. $\mathcal{f}$ Psychosom Res 986;30:589-600.

9 Brown GW, Harris T. Social origins of depression. A study of psychiatric disorder in women. London: Tavistock, 1978

10 John C, Schwenk TL, Roi LD, Cohen M. Medical care and demographic characteristics of 'difficult' patients. I Fam Pract 1987;24:607-10.

11 Drossman DA. The problem patient. Evaluation and care of medical patients with psychosocial disturbances. Ann Intern Med 1978:88:366-72.

2 Ellis CG. Dysphoria, a non-disease. S Afr Med I 1987;71:69-70.

13 Groves JE. Taking care of the hateful patient. N Engl f Med 1978;298:883-7.

14 Lewis E. Counter-transference problems in hospital practice. Br f Med Psych 1979;52:37-42.

15 Grant WB. The hated patient and his hating attendants. Med f Aust 1980;ii:727-9.

16 Lazare A. Shame and humiliation in the medical encounter. Arch Intern Med 1987;147:1653-8.

16 Lazare A. Shame and humiliation in the medical encounter. Arch Intem

18 Freeman GK, Button EJ. The clinical psychologist in general practice: a six-year study of Freeman GK, Button EJ. The clinical psychologist in general practice: a six-ye
consulting patterns for psychosocial problems. $\mathcal{F}$ R Coll Gen Pract 1984;34:377-80.

9 Goodwin JM, Goodwin JS, Kellner R. Psychiatric symptoms in disliked medical patients. JAMA 1979;241:1117-20

20 Fiske ST, Taylor SE. Social cognition. New York: Random House, 1984

21 Illingworth RS. Why irritated? Arch Dis Child 1988;63:567-8.

22 Balint M. The doctor, his patient and the illness. London: Pitman, 1964.

\section{The code for promoting drugs}

\section{Can do little to limit overenthusiastic advocacy}

Codes of practice are in vogue. They have been promulgated for the Stock Exchange, marketing in general, and the pharmaceutical industry in particular. They principally regulate affairs when formal legislation does not exist or standards of conduct are needed that go beyond what legislation may require. The code of practice of the Association of the British Pharmaceutical Industry tries to define good standards of marketing practice. Does it succeed?

The code lays down in over 20 major clauses and multiple subclauses what is or is not acceptable in promoting drugs. Some of the clauses are straightforward exhortations"Methods of promotion must never be such as to bring discredit upon, or reduce confidence in, the pharmaceutical industry." Others are statements of intent-"Information about medical products should accurately reflect current knowledge or responsible opinion . . . must be accurate, balanced and must not mislead either directly or by implication ... . [and] must be capable of substantiation." Apart from these general statements there are specific injunctionssuch as that "new" should not be used in describing products that have been available for over 12 months. Superlatives and hanging comparatives_-such as "better" or "stronger"- should not be used: "Claims for superior potency per unit weight are meaningless . . . unless linked to some practical advantage." Descriptions are also included of what may appear in promotional material, of appropriate means of graphic display, and of conduct during discussion with doctors.

If the consumer (in this case the prescribing doctor) is educated and intelligent, if there is free access to unbiased sources of information, and if prescribing does not bring a differential reward according to the agent prescribed we should have cost effective and efficient prescribing. Unfortunately there is little reason for believing that this is how things are. Although prescribers do not gain (except in prescribing practices) from choosing the more rather than the less expensive drug, the pressures to be cost effective are limited. In addition, the short snappy messages of advertisers tend inevitably to be more memorable than the measured cadences of official or semiofficial publications exhorting prescribers to be cost effective. This might not matter if clinical differences between drugs were always obvious.

If, as is likely, slogans are better received than sense, does the code amount to more than window dressing? If the code 